\title{
Screening of melatonin, a-tocopherol, folic acid, acetyl-L-carnitine and resveratrol for anti-dengue 2 virus activity
}

\author{
Atchara Paemanee ${ }^{1,2}$, Atitaya Hitakarun ${ }^{1}$, Sittiruk Roytrakul ${ }^{2}$ and Duncan R. Smith ${ }^{1 *}$ (D)
}

\begin{abstract}
Objective: Infections with the mosquito transmitted dengue virus (DENV) are a significant public health burden in many parts of the world. Despite the introduction of a commercial vaccine in some parts of the world, the majority of the populations at risk of infection remain unprotected against this disease, and there is currently no treatment for DENV infection. Natural compounds offer the prospect of cheap and sustainable therapeutics to reduce the disease burden during infection, and thus potentially alleviate the risk of more severe disease. This study evaluated the potential anti-DENV 2 activity of five natural compounds namely melatonin, a-tocopherol, folic acid, acetyl--L-carnitine and resveratrol in two different cell lines.

Results: Screening of the compounds showed that one compound (acetyl-L-carnitine) showed no effect on DENV infection, three compounds (melatonin, a-tocopherol and folic acid) slightly increased levels of infection, while the 5th compound, resveratrol, showed some limited anti-DENV activity, with resveratrol reducing virus output with an $\mathrm{EC}_{50}$ of less than $25 \mu \mathrm{M}$. These results suggest that some commonly taken natural compounds may have beneficial effects on DENV infection, but that others may potentially add to the disease burden.
\end{abstract}

Keywords: Flavivirus, Dengue virus, Melatonin, a-Tocopherol, Folic acid, Acetyl-L-carnitine, Resveratrol

\section{Introduction}

Dengue is currently considered as the most important arthropod-borne viral disease [1]. It is caused by dengue virus (DENV) which is transmitted by female Aedes mosquitoes, particularly Aedes aegypti [2]. Using the population data of 2010 and a geostatistical model, Bhatt and colleagues estimated that approximately 390 million dengue infections occur globally every year, with 96 million symptomatic cases [3]. Other studies have estimated that more than 22,000 deaths are reported annually [4]. Overall, an estimated 3.9 billion people are at risk of dengue virus infection in almost 128 countries in tropical and subtropical regions [5]. Dengue infection can occur

\footnotetext{
*Correspondence: duncan_r_smith@hotmail.com; duncan.smi@mahidol. acth

${ }^{1}$ Molecular Pathology Laboratory, Institute of Molecular Biosciences, Mahidol University, Salaya Campus, 25/25 Phuttamonthol Sai 4, Salaya, Nakorn Pathom 73170, Thailand

Full list of author information is available at the end of the article
}

with one of four DENV serotypes (DENV 1-4), and cause clinical manifestations ranging from self-limiting febrile illness, dengue fever to life-threatening dengue hemorrhagic fever which can progress to dengue shock syndrome (DSS) [2]. There is no specific drug to treat DENV infection, and care is mainly supportive [6]. Studies have shown a relationship between viral burden and disease severity [7], and thus there is interest in compounds that have anti-DENV effects, as these may serve to reduce severity if administered early in infection.

De novo drug discovery is both prohibitively expensive [8] and time consuming, and so studies in a wide range of fields have started to explore natural compounds as a way of cutting short the drug development process and additionally developing therapies that are more affordable. This study investigated the anti-DENV effects of 5 commonly used natural compounds that have been shown to have activity against other viruses, or to have the potential to have anti-viral activity, namely 
melatonin, $\alpha$-tocopherol, folic acid, acetyl-L-carnitine and resveratrol.

\section{Main text \\ Materials and methods \\ Compounds}

Acetyl-L-carnitine (MW 239.70, $\geq 99 \%$ purity; Cat.No. A6706, Merck KGaA, Darmstadt, Germany) was prepared as a stock solution of $50 \mathrm{mM}$ in Dulbecco's modified Eagle's medium (DMEM, Merck KGaA, Darmstadt, Germany), 10\% FBS. Melatonin (MW 232.2, $\geq 98 \%$ purity; Cat.No. 444300, Merck KGaA) was prepared as a stock solution of $200 \mathrm{mM}$ in $1 \mathrm{ml}$ of $100 \%$ DMSO. $\alpha$-Tocopherol (MW 430.71, $\geq 95.5 \%$ purity, Cat.No. 258024, Merck KGaA) was prepared as a stock solution of $100 \mathrm{mM}$ in EtOH. Folic acid (MW 441.4, $\geq 97 \%$ purity, Cat.No. F7876, Merck KGaA) was prepared as a stock solution of $50 \mathrm{mM}$ in $1 \mathrm{M} \mathrm{NaOH}$. Resveratrol (MW $228.2, \geq 98 \%$ purity, Cat No 554325, Merck KGaA) was prepared as a stock solution of $100 \mathrm{mM}$ in $100 \%$ DMSO.

\section{Cell culture and virus}

The human hepatocellular carcinoma cell line HepG2 $\left(\right.$ ATCC $^{\circledR}$ HB- $8065^{\mathrm{TM}}$ ) and the human embryonic kidney cell line HEK293T/17 (ATCC ${ }^{\circledR}$ CRL-11268 ${ }^{\mathrm{TM}}$ ) were cultivated in Dulbecco's modified Eagle's medium (DMEM, Merck KGaA) supplemented with $10 \%$ heat inactivated fetal bovine serum (FBS, FBS; Gibco, Merck KGaA), $100 \mathrm{U} / \mathrm{ml}$ penicillin and $100 \mu \mathrm{g} / \mathrm{ml}$ streptomycin (PAA Laboratories, Pasching, Austria) in a $175 \mathrm{~cm}^{2}$ tissue culture flask at $37{ }^{\circ} \mathrm{C}$ in $5 \% \mathrm{CO}_{2}$. Rhesus monkey kidney cells LLC-MK2 $\left(\right.$ ATCC $^{\circledR}$ CCL-7 ${ }^{\text {TM }}$ ) cells were cultivated in DMEM supplemented with 5\% FBS and 100 units/ $\mathrm{ml}$ of penicillin and $100 \mu \mathrm{g} / \mathrm{ml}$ of streptomycin at $37^{\circ} \mathrm{C}$ in an incubator with $5 \% \mathrm{CO}_{2}$. C6/36 (Aedes albopictus, ATCC $^{\circledR}$ CRL-1660 ${ }^{\mathrm{TM}}$ ) cells were cultivated in minimum essential medium (MEM; Merck KGaA) supplemented with $10 \%$ FBS, 100 units $/ \mathrm{ml}$ of penicillin and $100 \mu \mathrm{g} / \mathrm{ml}$ of streptomycin at $28{ }^{\circ} \mathrm{C}$. DENV 2 (strain 16681) was propagated in C6/36 cells and the viral titer was determined by standard plaque assay in LLC-MK2 cells essentially as described elsewhere [9].

\section{Determination of cytotoxicity}

Cytotoxicity of the natural compounds in the range 0.0001-10 mM (Melatonin, ALCAR and $\alpha$-tocopherol) or $0.0001-5 \mathrm{mM}$ (folic acid and resveratrol) was evaluated by the MTT assay (Merck KGaA) both in infected and uninfected cells.

\section{Virus infection for compound screening}

HepG2 and HEK293T/17 cells were seeded in 12-well culture plates at a density that allowed $90 \%$ confluence to be reached within $24 \mathrm{~h}$. The cells were washed in $1 \times$ PBS and incubated with $500 \mu \mathrm{l}$ of DENV 2 containing the desired multiplicity of infection (MOI) for $2 \mathrm{~h}$. HepG2 cells were infected at MOI 2 and 5, while HEK293T/7 cells were infected at MOI 0.5 and 2 at $37^{\circ} \mathrm{C}$. Mock infection (no virus) was undertaken in parallel. After $2 \mathrm{~h}$ of virus infection, medium was replaced with 2 concentrations of each compound in DMEM with 10\% FBS and then incubated at $37{ }^{\circ} \mathrm{C}, 5 \% \mathrm{CO}_{2}$. After 24-h incubation, cells were collected for determination of the degree of infectivity. For some compounds, cell supernatant was collected and levels of virus production determined by standard plaque assay.

\section{Flow cytometry}

Flow cytometry to determine percentage cell infection was undertaken using a pan specific anti-dengue $\mathrm{E}$ protein antibody HB114 [10] as a primary antibody and a goat anti mouse IgG conjugated with FITC as secondary antibody as described elsewhere [11]. Cells were run on a BD FACSCalibur (Becton-Dickinson, BD Bioscience, San Jose, CA) and data was analyzed using the CellQuest Pro software.

\section{Statistical analysis}

All data were analyzed using the GraphPad Prism program (GrapPad Software Inc., San Diego, CA). Statistical analysis of significance was undertaken by One-Way ANOVA on raw data reads using SPSS (SPSS Inc., Chicago, IL). $\mathrm{EC}_{50}$ values were calculated using the freeware ED50plus (v1.0) software (http://sciencegateway.org/ protocols/cellbio/drug/data/ed50v10.xls).

\section{Results}

To undertake screening of compounds for anti-DENV activity, two cell lines were selected, the human embryonic kidney cell line HEK293T/17, and the human hepatocellular cell line HepG2. Both cell lines are commonly used in analysis of DENV infection, although HET293T/17 cells do not represent a normal tissue involved in DENV infection.

Five natural products (melatonin, $\alpha$-tocopherol, folic acid, acetyl-L-carnitine and resveratrol) were selected for screening for possible anti-DENV 2 activity. All compounds were initially screened for cytotoxicity in both cell lines using the MTT assay. Cytotoxic effects were determined for both uninfected cells and DENV 2 infected cells in the range of 0.0001-10 mM $(0.1-10,000 \mu \mathrm{M})$ for acetyl-L-carnitine, melatonin and $\alpha$-tocopherol, and the range of $0.0001 \mathrm{mM}(0.1-$ $5000 \mu \mathrm{M})$ for folic acid and resveratrol, with treatment being undertaken for $24 \mathrm{~h}$. Results showed little difference in cytotoxicity profiles of the compounds between 
DENV 2 infected and uninfected cells. Thus there was no cytotoxic synergism between the compounds and DENV infection. Melatonin (Fig. 1a, b), $\alpha$-tocopherol (Fig. 2a, b) and acetyl-L-carnitine (Additional file 1: Figure S1A, B) all showed evidence of cytotoxicity at compound concentrations of $10 \mathrm{mM}$. Folic acid (Additional file 2: Figure S2A, B) and/or the vehicle showed a slight positive effect in both HEK293T/17and HepG2 cells at concentration of $1 \mathrm{mM}$, but this was not seen at a higher concentration. Cytotoxicity was observed for resveratrol at concentrations above $0.05 \mathrm{mM}$ in HEK293T/17 cells, and above $1 \mathrm{mM}$ in HepG2 cells (Fig. 3a, b). Based on the cytotoxicity profiles, two concentrations were selected for each compound for assay of antiviral activity, which were 50 and $500 \mu \mathrm{M}$ for acetyl-L-carnitine and melatonin, 0.5 and $1.0 \mathrm{mM}$ for $\alpha$-tocopherol, 0.1 and $0.5 \mathrm{mM}$ for folic acid. For resveratrol which showed significant cell type variation in cytotoxicity, values of 25 and $50 \mu \mathrm{M}$ were used for HEK293T/17 cells, and 50 and $100 \mu \mathrm{M}$ were used for HepG2 cells. For all experiments, infections were undertaken at MOI 0.5 and 2 for HEK293T/17 cells and 2 and 5 for HepG2 cells due to different cell susceptibility to infection [12].

\section{Melatonin}

Melatonin ( $N$-acetyl-5-methoxy tryptamine) is a natural hormone that is primarily produced by the pineal gland and regulates the circadian rhythm [13], and exogenous melatonin is often administered to adjust the sleep-wake cycle [14]. However, studies have shown that melatonin also has significant antiviral effects. Melatonin has been shown to have some effects in animal models of Venezuelan equine encephalitis virus $[15,16]$, Semliki Forest virus [17], West Nile virus [17], respiratory syncytial virus [18] and its use has been proposed in humans infected with Ebola virus [19]. In this study, melatonin showed a slight proviral effect upon DENV 2 infection in HEK293T/17 cells (Fig. 1c) under conditions of the lowest MOI used, and the highest concentration of melatonin, but no effect was seen in HepG2 cell (Fig. 1d).

\section{a-Tocopherol}

Vitamin E refers to compounds classed as both tocopherols and tocotrienols. There are four vitamin E tocopherols, termed $\alpha-, \beta-, \gamma$ - and $\delta$-, and while $\gamma$-tocopherol is the most abundant form of vitamin E, $\alpha$-tocopherol is the second most abundant and the most biologically active
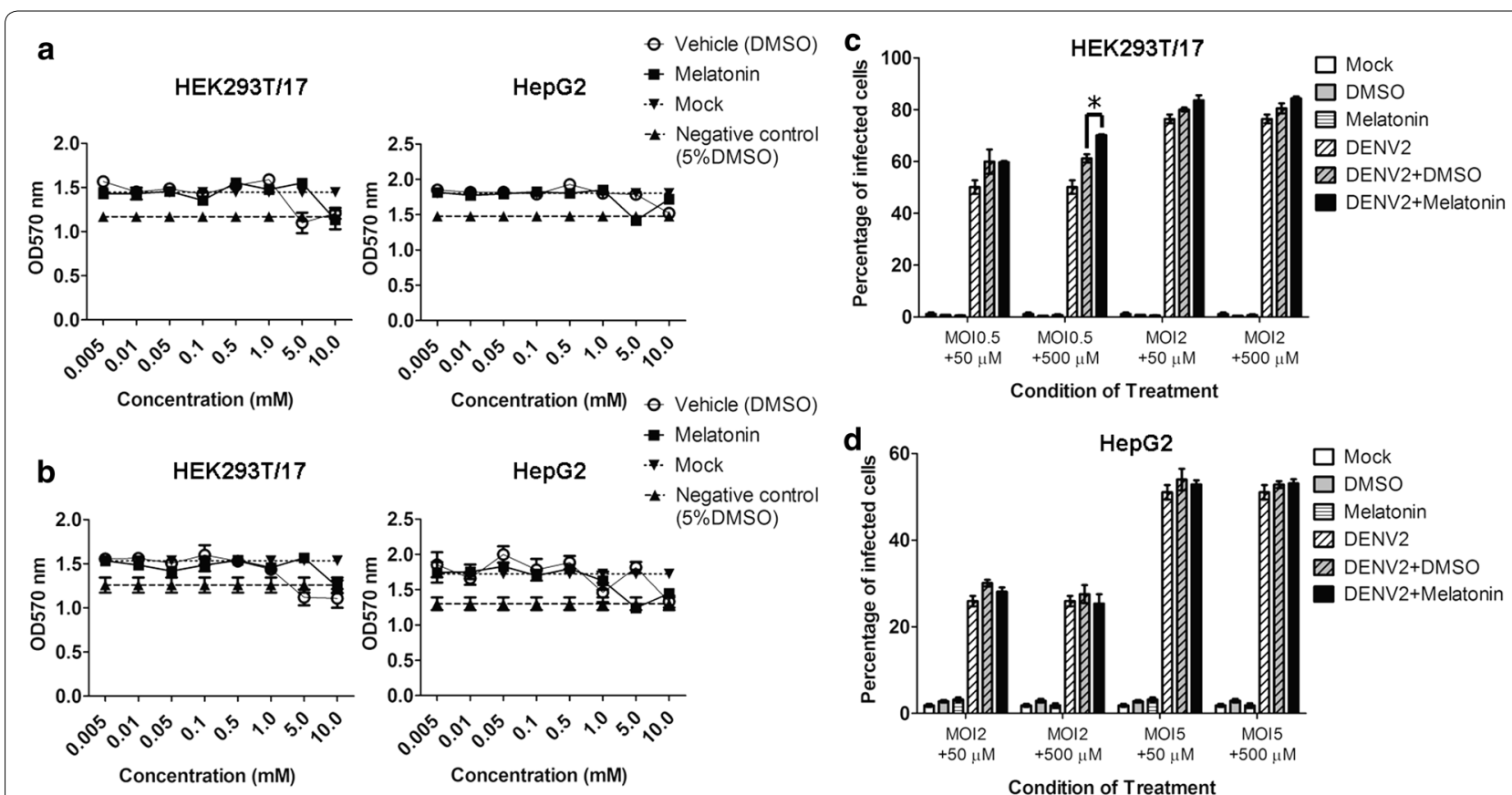

Fig. 1 Effect of melatonin on DENV 2 infection of HEK293T/17 and HepG2 cells. The cytotoxicity of melatonin was assessed in a uninfected HEK293T/17 (left panel) and HepG2 (right panel) and b DENV 2 infected HEK293T/17 (left panel and HepG2 (right panel) cells. Infected and uninfected cells were incubated with various concentration of melatonin for $24 \mathrm{~h}$ and viability was assessed using MTT assay. The experiments were performed independently in triplicate in parallel with control treatments and mock. A negative of cells incubated with 5\% DMSO in complete media was included. The standard deviation (SD) of mean are presented as error bars. c HEK293T/17 cells were infected with DENV 2 at MOI 0.5 and 2, and then treated with or without 50 and $500 \mu \mathrm{M}$ of melatonin or with vehicle only. d HepG2 cells were infected with DENV 2 at MOI 2 and 5 and then treated with or without 50 and $500 \mu \mathrm{M}$ of melatonin or with vehicle only. At $24 \mathrm{~h}$ post infection cells were analyzed by flow cytometry to determine the percentage infection. All experiments were undertaken independently in triplicate. Error bar showed mean \pm SD $\left({ }^{*} \mathrm{p}\right.$ value $\left.\leq 0.05\right)$ 


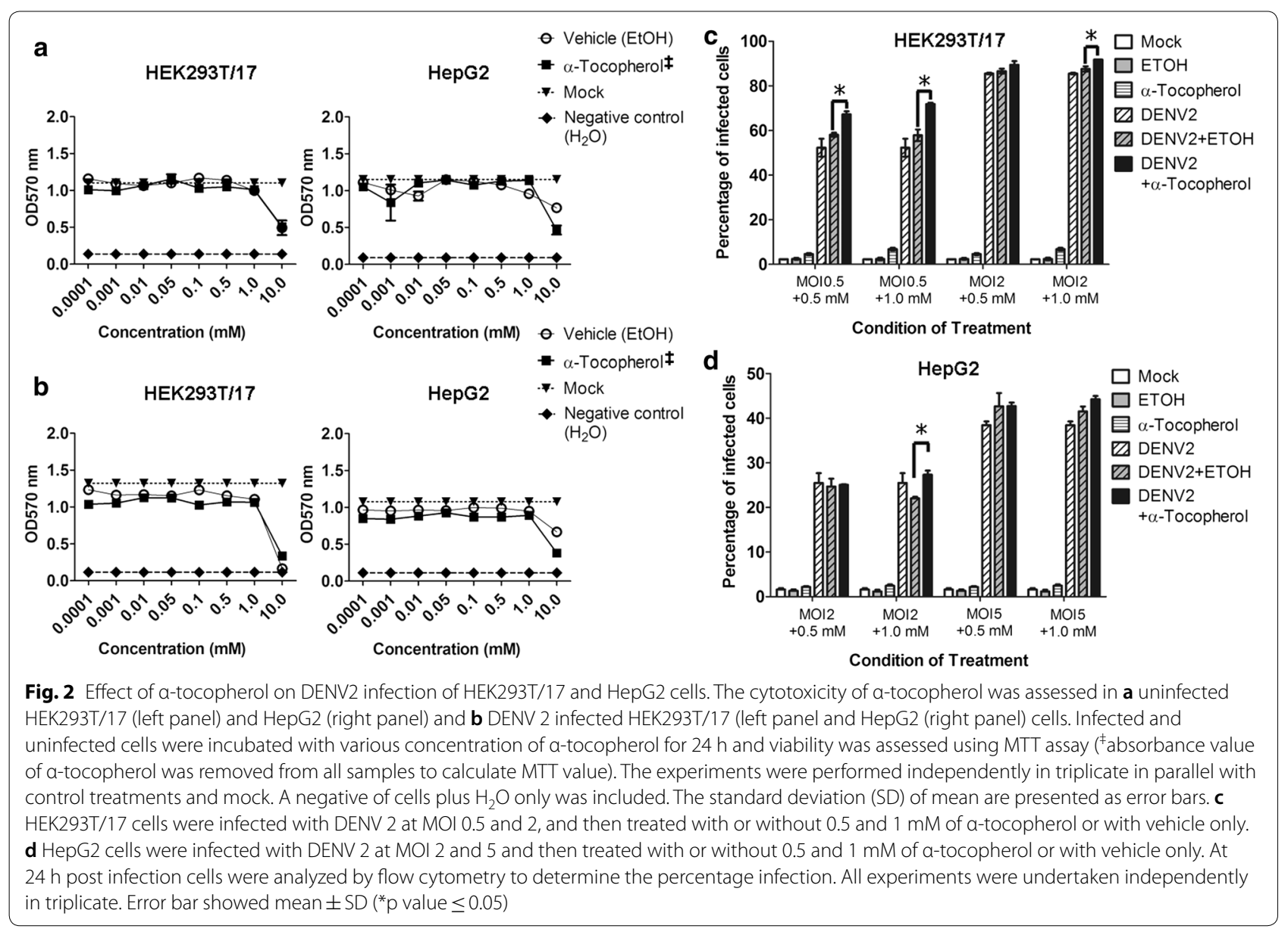

form [20]. Vitamin E has well known antioxidant properties, through its ability to donate a hydrogen group from its free hydroxyl group to the free radical, with the generation of a stable free radical form of vitamin E. However, a number of non-antioxidant activities of vitamin $E$ have been demonstrated [21]. $\alpha$-Tocopherol has been reported to have some effects in dengue patients [22] and has proposed benefits for influenza virus A infection [23], as well as possible activity against hepatitis B [24] and C [25]. In this study, $\alpha$-tocopherol showed proviral effects, particularly in HEK293T/17 cells (Fig. 2c), where the percentage of infection was increased significantly under most condition combinations tested. However, only a small effect was seen in HepG2 cells under conditions of the highest concentration and lowest MOI tested (Fig. 2d).

\section{Acetyl-L-carnitine}

Acetyl-L-carnitine (ALCAR) is the acetylated form of L-carnitine a molecule naturally produced by the body and the acetylated form of L-carnitine is able to cross the blood brain barrier [26]. L-Carnitine functions primarily to transport activated long chain fatty acids into mitochondria for degradation by $\beta$-oxidation, and $\beta$-oxidation has been proposed to be important in DENV replication [27]. In addition, L-carnitine has been shown to have activity against hepatitis $C$ virus [28]. In this study, ALCAR was shown to have no effect on DENV 2 infection in either cell line (Additional file 1: Figure S1C, D).

\section{Folic acid}

Folic acid is the synthetic form of vitamin B9, while folate is the naturally occurring form found in food. Folic acid is essential for nervous system development, and is a commonly administered supplement to pregnant mothers to prevent neural tube defects [29]. Folic acid is also important in the synthesis of RNA and DNA, and is particularly important in rapidly dividing cells [30]. Folic acid additionally plays a role in the formation of red blood cells [30]. Folic acid has not previously been explored for anti-viral activity, although the metabolically active form of folic acid, folinic acid has been described as having 


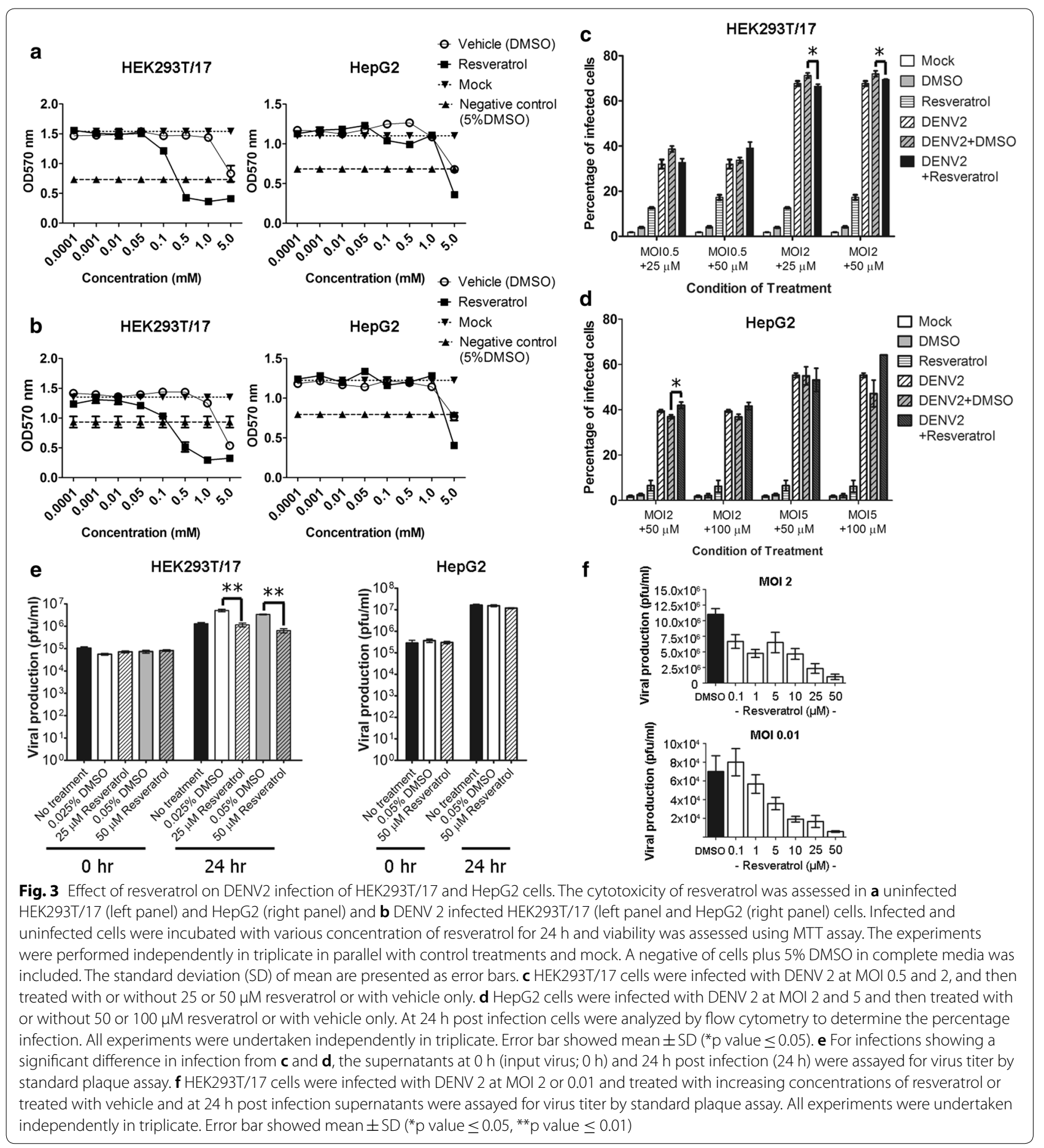

pro-flaviviral effects through the thymidine synthesis pathway [31]. In this study, folic acid had little effect upon DENV 2 infection in either cell line (Additional file 2: Figure S2C, D), although a slight proviral effect was seen at the highest concentration examined in HepG2 cells (Additional file 2: Figure S2D).

\section{Resveratrol}

Resveratrol (3,5,4'-trihydroxy-trans-stilbene) is a hydroxylated derivative of stilbene, and a phytoalexin which is produced in response to pathogen attack in some plants. It is found in nature in several foods including grapes and blueberries [32]. Considerable attention 
has been focused on resveratrol for potential anti-cancer [33], anti-obesity [34], anti-neurodegeneration [35] and cardio-protective activities [32]. Studies have shown that resveratrol has activity against a number of viruses including HIV [36], Middle East respiratory syndrome coronavirus (MERS-CoV) [37], influenza A virus [38], poxvirus [39] and enterovirus 71 [40].

As noted earlier, resveratrol showed significant cytotoxicity in HEK293T cells, but that HepG2 cells were somewhat less sensitive to the cytotoxic effects of the compound (Fig. 3a, b). However, infection with DENV 2 in the presence of resveratrol (at 25 and $50 \mu \mathrm{M})$ in HEK293T/17 cells showed a significant reduction in the level of infection (Fig. 3c), while a slight increase in infection levels was seen in HepG2 cells (Fig. 3d) with the lowest MOI and $50 \mu \mathrm{M}$ resveratrol. We observed some background in the flow cytometry with resveratrol (Fig. 3) and this might be related to the protein binding ability of resveratrol [41]. However, subtraction of the background did not alter the result. To further investigate the effect of resveratrol in DENV 2 infection, the effect on virus production was determined by standard plaque assay. The virus titer was determined at $0 \mathrm{~h}$ (input virus) and at $24 \mathrm{~h}$ post infection. The results (Fig. 3e) showed that, consistent with the reduction in the level of cellular infection (Fig. 3c), there was a reduction in the level of virus produced with treatment with resveratrol in HEK293T/17 cells at $24 \mathrm{~h}$ post infection, but not in HepG2 cells (Fig. 3e). The reduction of virus output observed was the order of approximately $1 \log _{10}$. To determine the $\mathrm{EC}_{50}$ of resveratrol on virus production, the experiment was repeated in HEK293T/17 cells with concentrations of $0,0.1,1,5,10,25$ and $50 \mu \mathrm{M}$ resveratrol. Results of the standard plaque assay are shown in Fig. 3f. The $\mathrm{EC}_{50}$ value was determined as $24.37 \mu \mathrm{M}$. Finally, the experiment was undertaken at a lower MOI of 0.01 . Results (Fig. 3f) showed a dose dependent reduction of virus production, with an $\mathrm{EC}_{50}$ value of $11.37 \mu \mathrm{M}$. While the reduction in level of infection and virus output is significant in HEK293T/17 cells, it compares poorly to other natural compounds such as andrographolide, which reduces DENV 2 virus output by $2.5 \log _{10}[11]$.

\section{Conclusion}

These results suggest that some commonly taken natural compounds may have beneficial effects on DENV infection, but that others may potentially add to the disease burden.

\section{Limitations}

1. Only one of the four DENV serotypes was examined.

2. Cytotoxic effects limited the concentration test range of compounds.

\section{Additional files}

Additional file 1. Effect of acetyl-L-carnitine on DENV2 infection of HEK293T/17 and HepG2 cells.

Additional file 2. Effect of folic acid on DENV2 infection of HEK293T/17 and HepG2 cells.

\begin{abstract}
Abbreviation
DENV: dengue virus.

Authors' contributions

SR and DRS designed the study, AP and AH undertook all experimental work, $\mathrm{AP}$ and $\mathrm{AH}$ analyzed the data, AP and DRS wrote the manuscript. All authors read and approved the final manuscript.
\end{abstract}

\section{Author details}

${ }^{1}$ Molecular Pathology Laboratory, Institute of Molecular Biosciences, Mahidol University, Salaya Campus, 25/25 Phuttamonthol Sai 4, Salaya, Nakorn Pathom 73170, Thailand. ${ }^{2}$ Proteomics Research Laboratory, Genome Technology Research Unit, National Center for Genetic Engineering and Biotechnology, National Science and Technology Development Agency, 113 Thailand Science Park, Phahonyothin Road, Khlong Nueng, Khlong Luang, Pathumthani 12120, Thailand.

\section{Acknowledgements}

Not applicable.

\section{Competing interests}

The authors declare that they have no competing interests.

\section{Availability of data and materials}

All data generated or analysed during this study are included in this published article.

\section{Consent for publication}

Not applicable.

Ethics approval and consent to participate

Not applicable.

\section{Funding}

This work was supported by Grants from Mahidol University and the Thailand Research Fund (BRG6080006 and IRN60W0002). AH is supported by a Thailand Graduate Institute of Science and Technology (TGIST) scholarship from the National Science and Technology Development Agency (NSTDA), Thailand.

\section{Publisher's Note}

Springer Nature remains neutral with regard to jurisdictional claims in published maps and institutional affiliations.

Received: 22 March 2018 Accepted: 9 May 2018

Published online: 16 May 2018

\section{References}

1. Murray NEA, Quam MB, Wilder-Smith A. Epidemiology of dengue: past, present and future prospects. Clin Epidemiol. 2013;5:299. 
2. Gubler DJ. Dengue and dengue hemorrhagic fever. Clin Microbiol Rev. 1998;11:480-96.

3. Bhatt S, Gething PW, Brady OJ, Messina JP, Farlow AW, Moyes CL, Drake $J M$, Brownstein JS, Hoen AG, Sankoh O. The global distribution and burden of dengue. Nature. 2013;496:504-7.

4. Gubler DJ. Dengue, urbanization and globalization: the unholy trinity of the 21st century. Trop Med Health. 2011;39:S3-11.

5. Brady OJ, Gething PW, Bhatt S, Messina JP, Brownstein JS, Hoen AG, Moyes CL, Farlow AW, Scott TW, Hay SI. Refining the global spatial limits of dengue virus transmission by evidence-based consensus. PLoS Negl Trop Dis. 2012;6:e1760.

6. WHO. Dengue: guidelines for diagnosis, treatment, prevention and control. Geneva: World Health Organization; 2009.

7. Vaughn DW, Green S, Kalayanarooj S, Innis BL, Nimmannitya S, Suntayakorn S, Endy TP, Raengsakulrach B, Rothman AL, Ennis FA, Nisalak A. Dengue viremia titer, antibody response pattern, and virus serotype correlate with disease severity. J Infect Dis. 2000;181:2-9.

8. Avorn J. The $\$ 2.6$ billion pill —-methodologic and policy considerations. N Engl J Med. 2015;372:1877-9.

9. Sithisarn P, Suksanpaisan L, Thepparit C, Smith DR. Behavior of the dengue virus in solution. J Med Virol. 2003;71:532-9.

10. Henchal EA, Gentry MK, McCown JM, Brandt WE. Dengue virus-specific and flavivirus group determinants identified with monoclonal antibodies by indirect immunofluorescence. Am J Trop Med Hyg. 1982;31:830-6.

11. Panraksa P, Ramphan S, Khongwichit S, Smith DR. Activity of andrographolide against dengue virus. Antiviral Res. 2017;139:69-78.

12. Tongluan N, Ramphan S, Wintachai P, Jaresitthikunchai J, Khongwichit S, Wikan N, Rajakam S, Yoksan S, Wongsiriroj N, Roytrakul S, Smith DR. Involvement of fatty acid synthase in dengue virus infection. Virol J. 2017;14:28.

13. Cajochen C, Krauchi K, Wirz-Justice A. Role of melatonin in the regulation of human circadian rhythms and sleep. J Neuroendocrinol. 2003:15:432-7.

14. Lyseng-Williamson KA. Melatonin prolonged release: in the treatment of insomnia in patients aged $>/=55$ years. Drugs Aging. 2012;29:911-23.

15. Bonilla E, Valero-Fuenmayor N, Pons H, Chacin-Bonilla L. Melatonin protects mice infected with Venezuelan equine encephalomyelitis virus. Cell Mol Life Sci. 1997:53:430-4.

16. Montiel M, Bonilla E, Valero N, Mosquera J, Espina LM, Quiroz Y, AlvarezMon M. Melatonin decreases brain apoptosis, oxidative stress, and CD200 expression and increased survival rate in mice infected by Venezuelan equine encephalitis virus. Antivir Chem Chemother. 2015:24:99-108.

17. Ben-Nathan D, Maestroni GJ, Lustig S, Conti A. Protective effects of melatonin in mice infected with encephalitis viruses. Arch Virol. 1995;140:223-30.

18. Huang SH, Cao XJ, Liu W, Shi XY, Wei W. Inhibitory effect of melatonin on lung oxidative stress induced by respiratory syncytial virus infection in mice. J Pineal Res. 2010;48:109-16.

19. Tan DX, Korkmaz A, Reiter RJ, Manchester LC. Ebola virus disease: potential use of melatonin as a treatment. J Pineal Res. 2014;57:381-4.

20. Azzi A. Many tocopherols, one vitamin E. Mol Aspects Med. 2017. https:// doi.org/10.1016/j.mam.2017.06.004.

21. Zingg JM, Azzi A. Non-antioxidant activities of vitamin E. Curr Med Chem. 2004;11:1113-33.

22. Ahmed S, Finkelstein JL, Stewart AM, Kenneth J, Polhemus ME, Endy TP, Cardenas W, Mehta S. Micronutrients and dengue. Am J Trop Med Hyg. 2014;91:1049-56.

23. Friel $\mathrm{H}$, Lederman $\mathrm{H}$. A nutritional supplement formula for influenza $A$ (H5N1) infection in humans. Med Hypotheses. 2006;67:578-87.
24. Fiorino S, Bacchi-Reggiani L, Sabbatani S, Grizzi F, di Tommaso L, Masetti M, Fornelli A, Bondi A, de Biase D, Visani M, et al. Possible role of tocopherols in the modulation of host microRNA with potential antiviral activity in patients with hepatitis B virus-related persistent infection: a systematic review. Br J Nutr. 2014;112:1751-68.

25. Bunchorntavakul $\mathrm{C}$, Wootthananont $\mathrm{T}$, Atsawarungruangkit $\mathrm{A}$. Effects of vitamin E on chronic hepatitis C genotype 3: a randomized, double-blind placebo-controlled study. J Med Assoc Thai. 2014;97(Suppl 11):S31-40.

26. Inano A, Sai Y, Nikaido H, Hasimoto N, Asano M, Tsuji A, Tamai I. AcetylL-carnitine permeability across the blood-brain barrier and involvement of carnitine transporter OCTN2. Biopharm Drug Dispos. 2003;24:357-65.

27. Heaton NS, Randall G. Dengue virus-induced autophagy regulates lipid metabolism. Cell Host Microbe. 2010;8:422-32.

28. Tsukuda Y, Suda G, Tsunematsu S, Ito J, Sato F, Terashita K, Nakai M, Sho T, Maehara O, Shimazaki T, et al. Anti-adipogenic and antiviral effects of L-carnitine on hepatitis C virus infection. J Med Virol. 2017:89:857-66.

29. Balashova OA, Visina O, Borodinsky LN. Folate action in nervous system development and disease. Dev Neurobiol. 2018. https://doi.org/10.1002/ dneu.22579.

30. Lucock M. Folic acid: nutritional biochemistry, molecular biology, and role in disease processes. Mol Genet Metab. 2000;71:121-38.

31. Fischer MA, Smith JL, Shum D, Stein DA, Parkins C, Bhinder B, Radu C, Hirsch AJ, Djaballah H, Nelson JA, Fruh K. Flaviviruses are sensitive to inhibition of thymidine synthesis pathways. JVirol. 2013;87:9411-9.

32. Rauf A, Imran M, Suleria HAR, Ahmad B, Peters DG, Mubarak MS. A comprehensive review of the health perspectives of resveratrol. Food Funct. 2017:8:4284-305.

33. Ko JH, Sethi G, Um JY, Shanmugam MK, Arfuso F, Kumar AP, Bishayee A, Ahn KS. The role of resveratrol in cancer therapy. Int J Mol Sci. 2017; 18:2589.

34. Zhao Y, Chen B, Shen J, Wan L, Zhu Y, Yi T, Xiao Z. The beneficial effects of quercetin, curcumin, and resveratrol in obesity. Oxid Med Cell Longev. 2017:2017:1459497.

35. Sawda C, Moussa C, Turner RS. Resveratrol for Alzheimer's disease. Ann NY Acad Sci. 2017;1403:142-9.

36. Chan CN, Trinite B, Levy DN. Potent inhibition of HIV-1 replication in resting CD4 T cells by resveratrol and pterostilbene. Antimicrob Agents Chemother. 2017;61:e00408.

37. Lin SC, Ho CT, Chuo WH, Li S, Wang TT, Lin CC. Effective inhibition of MERS-CoV infection by resveratrol. BMC Infect Dis. 2017;17:144

38. Drago L, Nicola L, Ossola F, De Vecchi E. In vitro antiviral activity of resveratrol against respiratory viruses. J Chemother. 2008;20:393-4.

39. Cao S, Realegeno S, Pant A, Satheshkumar PS, Yang Z. Suppression of poxvirus replication by resveratrol. Front Microbiol. 2017;8:2196.

40. Zhang L, Li Y, Gu Z, Wang Y, Shi M, Ji Y, Sun J, Xu X, Zhang L, Jiang J, Shi W. Resveratrol inhibits enterovirus 71 replication and pro-inflammatory cytokine secretion in rhabdosarcoma cells through blocking IKKs/NFkappaB signaling pathway. PLoS ONE. 2015;10:e0116879.

41. N' soukpoé-Kossi CN, St-Louis C, Beauregard M, Subirade M, Carpentier R, Hotchandani S, Tajmir-Riahi HA. Resveratrol binding to human serum albumin. J Biomol Struct Dyn. 2006;24:277-83.

Ready to submit your research? Choose BMC and benefit from:

- fast, convenient online submission

- thorough peer review by experienced researchers in your field

- rapid publication on acceptance

- support for research data, including large and complex data types

- gold Open Access which fosters wider collaboration and increased citations

- maximum visibility for your research: over 100M website views per year

At BMC, research is always in progress.

Learn more biomedcentral.com/submissions 